\title{
DESAFIOS DA EDUCAÇÃO ESCOLAR INDÍGENA
}

Hellen Cristina Picanço Simas é aluna do doutorado em Linguística da UFPB, bolsista pelo programa Rh-Doutorado FAPEAM/CAPES. E-mail: india.parintintins@gmail.com Regina Celi Mendes Pereira é professora Doutora da UFPB. E-mail: reginacmps@gmail.com

\begin{abstract}
Resumo
Neste artigo são abordadas três dimensões importantes do processo educacional indígena no atual contexto sócio-histórico, necessárias para a sua compreensão: o que significam a Educação Escolar Indígena, a Educação Indígena e a Educação Não-Indígena. Nossas reflexões são respaldadas nas contribuições de Meliá (1979), Munduruku (2000), Santos (2006) e RCNEI (2005).
\end{abstract}

\section{INTRODUÇÃO}

O cenário acadêmico nunca esteve tão favorável às reflexões sobre interculturalidade, diversidade étnica e pluralidade dos fenômenos sociais. Nesse contexto, a temática indígena tem se destacado por se constituir como um espaço de discussão para o qual convergem diferentes interesses e perspectivas: políticas, econômicas, culturais e educacionais. No que se refere à perspectiva educacional, foco de nosso interesse, é importante que seja historiada a trajetória que marcou o processo de construção de uma identidade escolar para essa etnia.

Após 500 anos do contato com o branco, depois de muita mobilização e lutas, os grupos indígenas ainda existentes no Brasil conseguiram incluir no texto da Carta Magna os seguintes artigos e incisos relativos à sua educação escolar:

Artigo 210 - Serão fixados conteúdos mínimos para o ensino fundamental, de maneira a assegurar formação básica comum e respeito aos valores culturais e artísticos, nacionais e regionais.

2. O ensino fundamental regular será ministrado em língua portuguesa, assegurada às comunidades indígenas também a utilização de suas línguas maternas e processos próprios de aprendizagem.

Artigo 231 - São reconhecidos aos índios sua organização social, costumes, línguas, crenças e tradições, e os direitos originários sobre as terras que tradicionalmente ocupam, competindo à União demarcá-las, proteger e fazer respeitar todos os seus bens (Brasil, 2001, p. 207).

Estes dispositivos constitucionais marcam a história da Educação Escolar Indígena. Para ocupar o lugar da educação integracionista, realizada até então, uma educação específica, diferenciada, intercultural e bilíngue é pensada e nos anos subsequentes à instituição dos artigos na Carta Magna, muitos textos legais passam a se posicionar sobre o assunto e regulamentar o que determinou a Constituição.

Revista Escrita

Rua Marquês de São Vicente, 225 Gávea/RJ CEP 22453-900 Brasil

Ano 2010. Número 11. ISSN 1679-6888.

escrita@puc-rio.br 
O Decreto 26/91 atribui ao Ministério da Educação - MEC o poder de coordenar o processo Educacional Indígena e determina que os estados e municípios executem as ações determinadas pelo MEC, retirando, assim, da Fundação Nacional do Índio - FUNAI a responsabilidade sobre a matéria. A Portaria Interministerial 559/91 institui o seguinte: reconhecer e assumir a diversidade sociocultural e linguística do país e o direito à sua manutenção; estabelecer a criação dos Núcleos de Educação Escolar Indígena - NEEI - nas secretarias Estaduais de Educação; definir como prioridade a formação permanente de professores índios e de pessoal técnico das instituições para a prática pedagógica, determinando que os vencimentos dos professores indígenas sejam iguais aos dos demais professores da rede de ensino; estabelecer as condições sobre o calendário escolar, metodologia e materiais didáticos, visando à regulamentação das Escolas Indígenas.

Em 1993, o MEC, cumprindo o que a lei lhe determina, lança as Diretrizes para a Política Nacional de Educação Escolar Indígena e, em 1998, cria o Referencial Curricular Nacional para as Escolas Indígenas - RCNEI, documento que trata mais detalhadamente da Educação Escolar Diferenciada.

Em 1996, a Lei 9.394/96 - LDB que, na estrutura hierárquica das leis do país está abaixo da Constituição, em dois momentos se pronuncia a respeito da Educação Escolar Indígena, a saber: o primeiro é quando trata do ensino fundamental, no seu Art. 32 , $\S 2^{\circ}$, no qual reproduz totalmente o que estabelece o Art. 210 da Constituição anteriormente exposto; o segundo é quando trata das disposições gerais, no Art. 78 e 79 destacados a seguir:

Art. 78. O Sistema de Ensino da União, com a colaboração das agências federais de fomento à cultura e de assistência aos índios, desenvolverá programas integrados de ensino e pesquisa, para oferta de educação escolar bilíngüe e intercultural aos povos indígenas, com os seguintes objetivos: I - proporcionar aos índios, suas comunidades e povos, a recuperação de suas memórias históricas; a reafirmação de suas identidades étnicas; a valorização de suas línguas e ciências; II - garantir aos índios, suas comunidades e povos, o acesso às informações, conhecimentos técnicos e científicos da sociedade nacional e demais sociedades indígenas e não-índias. (Brasil, 2006, p.41).

Art. 79. A União apoiará técnica e financeiramente os sistemas de ensino no provimento da educação intercultural às comunidades indígenas, desenvolvendo programas integrados de ensino e pesquisa.

$\S 1^{\circ}$ Os programas serão planejados com audiência das comunidades indígenas [...] § $2^{\circ}$ Os programas a que se refere este artigo, incluídos nos Planos Nacionais de Educação, terão os seguintes objetivos: I - fortalecer as práticas sócio-culturais e a língua materna de cada comunidade indígena; II - manter programas de formação de pessoal especializado, destinado à educação escolar nas comunidades indígenas; III - desenvolver currículos e programas específicos, neles incluindo os conteúdos culturais correspondentes às respectivas comunidades; IV - elaborar e publicar sistematicamente material didático específico e diferenciado (Brasil, 2006, p.41).

No Art. 78, como pode ser observado, o ensino visa agora resgatar o que foi perdido com a educação integracionista e garantir ao indígena o direito de permanecer na sua identidade étnica e conhecer outras culturas, sem precisar incorporá-las. No Art. 79, a LDB abre espaço para os próprios indígenas fazerem parte do processo de elaboração dos projetos educacionais para sua comunidade. 
Seis anos depois é promulgada a Lei 10.172/01, que fixa as diretrizes e metas da educação a serem alcançados nos dez anos seguintes, conhecida como Plano Nacional da Educação - PNE. Ele possui um capítulo destinado a tratar da Educação Escolar Indígena. No primeiro momento, faz um diagnóstico de como a educação escolarizada tem chegado aos indígenas; depois, apresenta suas diretrizes e, por fim, estabelece seus objetivos e metas, sendo 21 no total.

Com o objetivo de fomentar as discussões sobre a temática que vem ganhando atenção nas últimas décadas, o presente artigo discute e define três conceitos-chave, a saber: o que é a Educação Escolar Indígena, a Educação Indígena e a Educação NãoIndígena. Ao mesmo tempo, mostra os precursores do letramento indígena e os motivos que levaram ao surgimento do mesmo.

\section{LETRAMENTO INDÍGENA: COMO INICIOU?}

Os portugueses que chegaram à terra brasílica, ao se depararem com as sociedades indígenas, logo trataram de classificá-las como bárbaras ou atrasadas, visto não dominarem a escrita, técnica considerada na época como capacidade avançada do intelecto. Para eles, os nativos só utilizavam a memória para assegurar os seus conhecimentos míticos, econômicos, sociais e transmitir sua história, sua cultura, suas lendas e suas línguas, por isso aos jesuítas foi inicialmente incumbida a missão de letrar os indígenas. Os europeus desconheciam, por exemplo, que as formas, traços e cores esculpidos nos corpos dos indígenas não eram simples adornos, mas símbolos que registravam rituais de passagens, clã e muitas outras informações sobre a pessoa, que só uma pesquisa detalhada pode explicar.

Os padres jesuítas vieram para as terras brasílicas a partir de 1549, sendo inaugurada com eles a primeira fase da Educação Escolar Indígena e da educação brasileira, em que se inicia o letramento do indígena e a formação de uma unidade nacional, conseguida principalmente com o combate às línguas nativas. Esses religiosos, segundo Azeredo (1996, p. 496), "eram disciplinados, possuíam uma fé inabalável e estavam dispostos a qualquer sacrifício", características indispensáveis a quem teria que se estabelecer numa terra hostil para implantar o poder da Igreja, defendendo e propagando a fé.

Seu ensino se caracterizava, segundo Azeredo (1996, p. 531), pelo apego à autoridade, à tradição escolástica e literária, restringindo-se aos estudos da gramática, retórica e latim; era um ensino autoritário, disciplinado, sistemático, medido, dosado, nitidamente abstrato, dogmático e conservador, tendo desinteresse pelas ciências naturais, línguas e literatura moderna.

No início do processo de catequização, dedicaram-se a aprender as línguas indígenas para melhor introduzirem os ensinamentos religiosos.

O objetivo geral dos missionários era a comunicação com os nativos para fim de propaganda religiosa. Isso quer dizer que a realidade lingüística só valia como meio. [...] Era preciso conhecer a língua para por meio dela entrar em contato com os indígenas e promover a catequese religiosa (Câmara Jr, 1979, p. 101).

Aspilcueta Navarro, segundo Azeredo (1996, p.498), foi o primeiro jesuíta a aprender a língua indígena e dela se utilizou desde 1550 na pregação aos ditos selvagens,

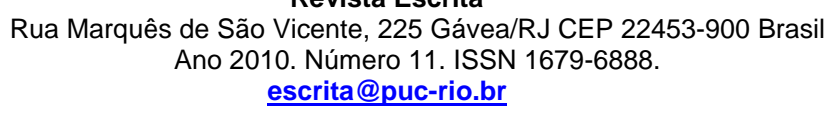


tornando-se o primeiro mestre e missionário dos nativos. Porém, o aprendizado da língua indígena era apenas um recurso para alcançar o objetivo dos missionários: catequizar os nativos. Por meio das línguas brasílicas ensinava-se, posteriormente, o português, obrigando os indígenas a abandonarem suas línguas e, consequentemente, grande parte seu imaginário e legado cultural, haja vista que a língua, segundo Mattoso Câmara (1979, p. 25), "se apresenta, pois, como um microcosmo da cultura. Tudo que esta última possui se expressa através da língua; mas também a língua em si mesma é um dado cultural”.

Os padres jesuítas, por 210 anos, foram os únicos educadores do Brasil, acumulando as atividades políticas, missionárias e educadoras ao mesmo tempo. Segundo Azeredo (1996, p. 497), a política dos jesuítas era abrir uma escola onde erguessem uma igreja, dessa forma, levantou-se sobre os alicerces do ensino toda obra de catequese e colonização. Os jesuítas, por meio do ensino do português e da catequese, lançaram as bases para a constituição da unidade nacional, a qual idealizavam nos moldes da cultura e da identidade portuguesa, em que a mesma fé, a mesma língua e os mesmos costumes seriam homogêneos, ou melhor, seriam impostos em detrimento da diversidade cultural e lingüística existente nas terras brasílicas. Os jesuítas começaram, portanto, “a forjar, na unidade espiritual, a unidade política de uma nova pátria” (Azeredo, 1996, p.500), fazendo da terra de mil povos terra de sepultamento de línguas.

O ensino da língua portuguesa visava, ao mesmo tempo, plasmar a unidade nacional, colonizar as terras brasílicas e expandir os domínios portugueses. "A colonização lingüística no século XVI sustenta ideologicamente o próprio ato da expansão marítima e religiosa” (Mariani, 2004, p. 29). Desta feita, um dos primeiros atos dos colonizadores foi introduzir seu idioma, pois ele configurava-se como uma instituição portuguesa, logo devia ser implantado junto aos nativos para confirmar seu domínio sobre eles.

Vale ressaltar que o letramento, ao qual se dedicavam os jesuítas, destinava-se aos índios homens, sendo as mulheres deixadas de fora do processo. Isso ocorria porque os europeus não tratavam as mulheres com respeito e igualdade. Nem as mulheres de famílias tradicionais e abastadas tinham acesso à educação escolar na Europa, o máximo que elas conseguiam era que lhes ensinassem as primeiras letras com a finalidade de lerem seus livros de reza. Poucas eram as que ainda conseguiam esse privilégio, como afirma Arilda Ribeiro:

Sendo também um alfabetizador, Trancoso foi procurado certa vez por uma dama da sociedade portuguesa que lhe pedia que lhe ensinasse a ler, já que suas vizinhas liam os livros de rezas na missa e ela não. Respondeu-lhe o poeta que como ela não tinha aprendido a ler na casa dos pais durante a infância, e agora já passava dos 20 anos de idade, deveria contentar-se com as contas do rosário de orações. No entanto, ele enviavalhe um abecedário moral, em que cada letra do alfabeto continha implícito um padrão de comportamento desejado na sociedade seiscentista. Por exemplo, a letra A significava que a mulher deveria ser amiga de sua casa, $\mathrm{H}$ humilde ao seu marido, $\mathrm{M}$ mansa, $\mathrm{Q}$ quieta, $\mathrm{R}$ regrada, S sisuda, entre outros. Encerrava dizendo que se ela cumprisse esse abecedário saberia mais do que aquelas senhoras que liam livros religiosos (Ribeiro, 2007, p. 79).

Nas sociedades indígenas, porém, o índio via a mulher como sua companheira, não se considerando melhor que ela. "O trabalho e o prazer do homem, como da mulher indígena, eram considerados eqüitativos e socialmente úteis” (Ribeiro, 2007, p. 80). Então, para os indígenas era inimaginável impedir que sua companheira tivesse acesso à leitura e à 
escrita. Não cogitavam, como os europeus, que o letramento da mulher fosse um perigo. Por isso, segundo Ribeiro (2007, p. 80): “a primeira reivindicação pela instrução feminina partiu dos indígenas brasileiros que foram ao Pe. Manoel de Nóbrega pedir que ensinassem suas mulheres a ler e escrever". O padre, vendo que seria boa a proposta, pois a instrução da mulher indígena lhe traria mais respeito e inibiria, assim, as relações variadas e sem bases religiosas entre branco e índias, mandou uma carta a Dona Catarina, rainha de Portugal, solicitando o ensino às mulheres indígenas. Pedido negado, afinal "por que então oferecer educação para mulheres 'selvagens', em uma colônia tão distante e que só existia para o lucro de Portugal?” (Ribeiro, 2007, p. 81).

Esse e outros aspectos que conheceremos em seguida entraram em conflito com a prática educativa indígena, constituindo-se o letramento numa atividade dolorosa e destrutiva dos valores e costumes nativos, ao mesmo tempo em que foi constitutiva de uma nova identidade para os povos da terra brasílica; identidade peculiar, posto ter marcas profundas de elementos identitários de índios, negros e brancos.

O modelo jesuítico de ensino pode ser dividido em três grandes etapas: no século XVI, foi para a catequese e conversão dos gentios e organização do sistema educacional jesuítico; no século XVII, trabalhou-se para a expansão horizontal desse sistema e no século XVIII, os religiosos empenharam-se na organização dos seminários. Essa expansão do modelo jesuítico deu tão certo porque, segundo Azeredo (1996, p.500), "para a catequese e colonização os padres usavam tanto a influência de meninos brancos quanto os próprios meninos índios, os quais iam ensinar seus pais na própria língua indígena”.

O letramento do indígena foi conseguido através das escolas primárias e pelas aulas de gramática e, aos poucos, o português se tornou idioma geral. Azeredo (1996, p.501) chega a afirmar que "a expansão do idioma correspondia à efetiva expansão do território", isto é, tanto a colonização quanto a catequização realizavam-se via letramento dos aborígines. A língua portuguesa só foi ameaçada pela língua tupinambá que, dentre as línguas indígenas, foi a que mais se expandiu, falada por índios, colonos e, inclusive, usada nos púlpitos. Por isso, em 1727, o primeiro ministro de Don João IV, Pombal, proibiu o uso da citada língua através do Diretório dos Índios, ato que pode ser registrado como uma das violências aos povos brasílicos. O Marquês de Pombal, em 1759, expulsou os jesuítas do reino e dos seus domínios e, em 1773 já era total a suspensão das Companhias de Jesus.

Porém, só uma década depois da expulsão dos jesuítas o Marquês de Pombal implanta o ensino público oficial (1772) e instituiu as aulas régias ${ }^{\mathrm{i}}$ e o subsídio literário ${ }^{\mathrm{ii}}$. As mudanças na Educação só significaram troca de nomenclatura e de interesse: as escolas da Companhia de Jesus tinham por objetivo maior servir aos interesses da Igreja; as escolas pombalinas tinham por objetivo mais relevante servir aos interesses do Estado, visto que Portugal estava em decadência e precisava se reerguer, para isso pretendia tirar o maior proveito de sua colônia Brasil. A expulsão dos jesuítas não significou, porém, mudança no ensino, mas destruição de todo um sistema educacional até então implantado, mantido e expandido.

\section{DE POVOS ÁGRAFOS A CIDADÃOS LETRADOS}

Os povos nativos, antes de os portugueses se estabelecerem nas terras brasílicas, possuíam um sistema social próprio e bem peculiar, logo, tinham uma forma de educar seus filhos a fim de torná-los cidadãos capazes de sobreviver no seu meio e dar prosseguimento ao seu sistema social vigente. Por isso, faz-se necessário diferenciar, neste momento do 
estudo, o que é a educação indígena, a educação não-indígena e a Educação Escolar Indígena.

Segundo o autor indígena Baniwa, Gersem dos Santos (2006, p. 129), “a educação indígena refere-se aos processos próprios de transmissão dos conhecimentos dos povos indígenas", isto é, refere-se à maneira de os povos nativos passarem seus conhecimentos e modos de viver na sua sociedade aos mais novos; representa seu modo de formar bons cidadãos para o seu grupo. Processo educativo este que ocorre durante todo o ciclo de vida de um indígena, sendo os principais momentos dessa trajetória, segundo Gersen dos Santos (2006), os seguintes: 1 - a vida antes do nascimento; 2 - nascimento; 3 - passagem da vida de criança à vida adulta e 4 - vida madura.

Assim, desde o momento da concepção de uma criança indígena, os pais e familiares adotam uma postura voltada para a formação de seu filho. Entre os Baniwa, por exemplo, "os pais precisam acordar e levantar de manhã cedo para tomarem banho antes que outros da casa se levantem, para evitar que a criança nasça fraca e cresça preguiçosa" (Santos, 2006, p. 132). Ou seja, tenta-se influenciar o comportamento e personalidade da criança desde o ventre da mãe, atitudes adotadas pelos Baniwa para influenciar diretamente o comportamento que a criança vai ter na sua vida adulta.

O nascimento é momento de celebração e confraternização entre os familiares da criança indígena. Em muitos grupos indígenas, o pajé faz suas orações e rituais pertinentes a esse momento; em muitos casos os nomes das crianças são escolhidos nessa ocasião, tendo uma relação direta com a personalidade que desejam para a criança, isto é, a escolha do nome visa influenciar também sua conduta futura. A passagem para a vida adulta, marcada com os rituais de iniciação, é uma "espécie de colação de grau, máximo de aprendizagem para a vida indígena” (Santos, 2006, p. 132). Em outras palavras, após vários anos aprendendo a ser um bom Xavante, ou bom Guarani, ou bom Baniwa, os ritos de iniciação à vida adulta comprovam que a criança indígena aprendeu tudo que precisava para viver na sua sociedade e ser um bom membro da mesma. A vida madura, por fim, é o momento de se ensinar tudo que se aprendeu aos novos membros da comunidade indígena. Os anciãos indígenas têm a missão de preparar as crianças para o ciclo da sua vida em sociedade, ou seja, têm que explicar e contar aos seus sucessores os conhecimentos indígenas, a fim de que a sua cultura continue a existir. Os anciãos são a experiência, a memória e os exemplos vivos dos costumes indígenas, como bem destaca Daniel Munduruku:

O conhecimento na sociedade indígena é dominado pelo mais velho. Mesmo que uma pessoa saiba todas as coisas sobre seu povo, sobre sua tradição, se houver alguém mais velho presente naquele espaço, é de direito que o mais velho responda o que lhe foi perguntado (Munduruku, 2000, p.92).

Para os que avaliam a cultura alheia tomando como parâmetro os princípios norteadores da sua cultura, essa forma de proceder pode parecer uma atitude de menosprezo aos mais novos, por não se aproveitar seu vigor e inteligência, mas na verdade essa postura representa para a sociedade indígena "o respeito pelo caminho que o outro percorre" (Munduruku, 2005, p. 92). Diante desta regra de conduta, então, seria falta de educação na cultura indígena uma pessoa mais nova responder um questionamento sobre valores e costumes, por exemplo, se houvesse na presença dela uma pessoa mais velha. 
O autor indígena Daniel Munduruku acrescenta mais dois aspectos que caracterizam a educação indígena: o reforço à identidade e a importância dos sonhos no processo educativo. Para o citado autor, "saber quem somos é o primeiro passo para o respeito ao outro que nasce pelo respeito a si mesmo. Quem se respeita, respeita o outro. Quem é livre, quer que o outro também seja” (Munduruku, 2000, p. 97). Por pensarem dessa maneira, os povos nativos cuidadosamente repassam sua tradição, evidenciando sua história, conquistas e costumes, a fim de construir na criança o conhecimento sobre seu povo e sobre si. Ou seja, conhecendo seu povo, a criança sabe de onde vem, quem ela é e qual sua expectativa de futuro. Essas informações ajudam-na a individualizar-se e definir-se a partir da história do grupo e, ao mesmo tempo, ajudam-na a entender-se como parte de um povo etnicamente diferente. Essa visão mostra como o passado é importante para a cultura nativa, é a herança da pessoa, a certeza de sua identidade.

O presente, por sua vez, estrutura-se nesse passado, porém ele só será “empolgante quando está estruturado, alicerçado por toda a teia da vida e de ancestralidade de uma pessoa ou grupo de pessoas. É aí que reside a força da tradição indígena, da família indígena, da educação indígena” (Munduruku, 2000, p.15).

Para o autor, as escolas nacionais enfrentam problemas para desenvolverem seu trabalho junto aos alunos devido à ausência de reforço à identidade deles, que deveria ser dado pela família. Uma vez que a maioria das famílias se ausenta desse processo, à instituição escolar é determinada a função de ensinar e educar ao mesmo tempo o aluno. Para ele, a educação é responsabilidade da família, pois a criança necessita de um referencial de valores, repassados, segundo Munduruku (2000, p. 15), por pessoas e não por instituições, como é o caso da escola. A solução desse problema, apontada pelo indígena, é fazer os alunos conhecerem seu passado, sua ancestralidade.

Tenho percebido que as escolas vivem um grande dilema na educação de seus alunos. A instituição escolar acabou assumindo um papel que antes cabia à família. Escola - ao menos como eu a entendo - nunca foi lugar para educar crianças e jovens [...] Uma solução é fazer com que os alunos busquem sua ancestralidade. Quando a gente se percebe continuador de uma história, nossa responsabilidade cresce e o respeito pela história do outro também. É preciso trazer a figura dos antepassados para dentro da escola (Munduruku, 2000, p. 15- 16).

A liberdade de sonhar é outro aspecto da educação indígena, como bem destaca o autor indígena:

Aprendi na sociedade que educar é fazer sonhar. Aprendi a ser índio, pois aprendi a sonhar. Ia para outras paragens. Passeava nelas, aprendia com elas. Percebi que na sociedade indígena educar é arrancar de dentro para fora, fazer brotar os sonhos e, às vezes, rir do mistério da vida (Munduruku, 2000, p. 71).

Para os povos indígenas, não há uma separação nítida entre a realidade dos sonhos, espiritual, e a realidade vivida cotidianamente. Em todos os elementos da natureza há um espírito, para todas as ocasiões, como colheita, plantio ou nascimento, há um festejo para agradecer aos espíritos responsáveis por conceberem a fartura. Dentro dessa perspectiva de mundo, o sonho passa a ser uma realidade, interior, mas que deve ser exercitada para se tornar realidade no mundo cotidiano e social. Daí o autor indígena falar que educar é 
arrancar de dentro para fora. Ou seja, o educador deve incentivar seus alunos a sonharem e a mostrar os caminhos para que seus sonhos materializem-se neste mundo.

Munduruku (2000, p. 60) acrescenta: "tudo está no grande círculo e faz parte de uma teia tramada pela vida de cada um e de todos”. Sonhos e realidade cotidiana são um contínuo, todavia devem-se trazer os sonhos para a realidade vivida diariamente e sonhar novamente. Por isso, o referido autor (2000, p. 98) sabiamente orienta: "não se deve ignorar os sonhos. Nem os nossos, nem os dos nossos alunos. Sonhar é a liberdade do nosso espírito, é um exercício de liberdade. Os sonhos moram na gente, assim como os valores. Eles são a expressão de nossas potencialidades". O indivíduo que se constitui sob essas bases vive melhor o presente, respeita o outro, entende a si mesmo e compreende sua importância para a comunidade.

A educação não-indígena, ou para o indígena, como escreve Bartomeu Melià (1979), é a educação escolar implantada nas comunidades indígenas desde o período jesuítico com o objetivo de integrar os povos nativos aos costumes eurocêntricos. Logo, os processos de transmissão, os valores, costumes, bem como os conhecimentos ensinados são do colonizador, do não-índio. Esse tipo de educação visa silenciar ou apagar a identidade indígena, imergindo as sociedades nativas no sistema social "nacional”, onde todos passem a falar a mesma língua e sigam o mesmo sistema econômico, social e cultural, numa idealizada rede homogênea de valores e de condutas.

Esse tipo de educação, por conseguinte, não formará o bom Xavante, ou o bom Baniwa, mas o índio marginal, que não é, apesar de dominar valores do branco ${ }^{\mathrm{iii}}$, um branco de fato, mas que também não será mais um nativo, sendo marginalizado duas vezes: uma pela sociedade não-índia que não reconhece no índio “aculturado”, como dizem, um verdadeiro membro da sua sociedade; outra, pela comunidade indígena, que não reconhece mais naquele sujeito os seus valores, o ser Xavante ou o ser Potiguara ou o ser Baniwa etc. Esse sujeito não domina mais as atividades e condutas necessárias para viver na sua comunidade nativa.

A educação não-indígena, ou para o indígena, não corresponde, portanto, aos anseios das sociedades indígenas e produz o índio marginal, aquele que se situa "na divisão de duas raças, na margem de duas culturas, sem pertencer a nenhuma delas" (Melià, 1979, p. 50). Diante deste contraponto de ideias e procedimentos educativos apresentados, destacamos a tabela comparativa que Melià (1979, p.52) faz sobre as duas formas de educação apresentadas (índia/não-índia).

Quadro 1: Educação Indígena x Educação Não-Indígena

\begin{tabular}{|l|l|}
\hline \multicolumn{1}{|c|}{ EDUCAÇÃO INDÍGENA } & \multicolumn{1}{c|}{ EDUCAÇÃO PARA O INDÍGENA } \\
\hline Educação informal e assistemática & Instrução formal e sistemática \\
\hline Transmissão oral & Alfabetização e usos de livros \\
\hline Rotina da vida diária & $\begin{array}{l}\text { Provocação de situações de ensino } \\
\text { artificiais }\end{array}$ \\
\hline Inserção na família & Deslocamento para a aula \\
\hline Sem escola & Com escola \\
\hline Comunidade educativa & Especialistas da educação \\
\hline Valor da ação & Valor da memorização \\
\hline “Aprender fazendo" & “Aprender memorizando” \\
\hline
\end{tabular}




\begin{tabular}{|l|l|}
\hline Valor do exemplo & Valor da coisa aprendida \\
\hline Sacralização do saber & Secularização do conhecimento \\
\hline Persuasão & Imposição \\
\hline Formação da “pessoa” & Adestramento para fazer “coisas” \\
\hline
\end{tabular}

Essa tabela comparativa sintetiza os principais aspectos em que a educação indígena opõe-se à educação não-indígena. Na cultura indígena, os conhecimentos (re)passados aos curumins $^{\text {iv }}$ e cunhantãs ${ }^{v}$ são os necessários para sua vida em grupo, a constituição, vivência em família, a manutenção de suas atividades econômicas, religiosas, políticas, bem como para a preservação de seus costumes e de sua identidade. Ela volta-se para as necessidades de seu grupo, ocorrendo fora de ambiente específico, como a escola.

A educação indígena não carece de artificializações de situações para passar uma informação, ela constrói-se coletivamente, no cotidiano, com a participação de todos os membros da sociedade. Curumins e cunhantãs vão aprendendo, na lida com seus pais, as atividades que na vida adulta, mais precisamente, desenvolverão. "Uma característica comum às sociedades indígenas é que cada experiência cognitiva e afetiva carrega múltiplos significados - econômicos, sociais, técnicos, rituais, cosmológicos” (Rcnei, 2005, p.23). Geralmente as atividades são ensinadas de acordo com o sexo da criança; se menino, com certeza terá mais atenção do pai, que o ajudará a confeccionar seus instrumentos; se menina, terá por mais tempo a companhia da mãe, que também lhe ensinará suas obrigações. Em ambos os casos, tudo é feito de acordo com a idade, respeitando os limites físicos e cognitivos. Lembra-se, contudo, que cada sociedade indígena tem suas peculiaridades e vê os fatos da vida de uma forma particular; além do mais, o clima, a geografia e a forma como se deu o “contato" vão influenciar as atividades e comportamentos do respectivo povo.

Segundo Melià (1979, p. 25), a natureza dos conhecimentos transmitidos na educação indígena pode ser sintetizada em três tipos: 1 - conhecimentos para o homem controlar a natureza; 2 - conhecimentos para o homem se relacionar consigo mesmo e com os outros; 3 - conhecimentos para o homem se relacionar com o sagrado. Esses três pilares, inconscientemente, organizam e orientam os processos pedagógicos indígenas. Processos geralmente de orientação face a face, oral, cujas avaliações são as observações das atitudes dos aprendizes que, por sua vez, se orientam também pelos exemplos diários de quem os ensina. Educação indígena, portanto, é o conjunto de práticas sociais de uma etnia indígena que orienta como devem ser as atitudes dos seus membros a fim de fortalecer sua identidade.

Por sua vez, a Educação Escolar Indígena, também conhecida como Educação Escolar Diferenciada, segundo o escritor Baniwa Gersem Santos,

diz respeito aos processos de transmissão e produção de conhecimentos não-indígenas e indígenas por meio da escola, que é uma instituição própria dos povos colonizadores. A educação escolar indígena refere-se à escola apropriada pelos indígenas para reforçar seus projetos socioculturais e abrir caminhos para o acesso a outros conhecimentos universais, necessários e desejáveis, a fim de contribuírem com a capacidade de responder às novas demandas geradas a partir do contato com a sociedade global (Santos, 2006, p. 129). 
Ou seja, é por meio dessa Educação Escolar Indígena que os povos indígenas do Brasil continuam mantendo sua alteridade sociocultural e, ao mesmo tempo, aprendem o que é a cultura da sociedade envolvente, sendo, por isso, intercultural, já que não se apaga uma ou outra cultura, mas se tenta estabelecer um diálogo entre elas. É consensual que o contato não pode ser negado, logo, não é mais possível para os nativos recusarem essa relação com a sociedade não-indígena.

Segundo o RCNEI (2005, p. 24), a Educação Escolar Indígena, para se constituir como tal, precisa se estabelecer sobre algumas bases: ser comunitária, intercultural, bilíngue/multilíngue, específica e diferenciada. Comunitária, porque a comunidade indígena é que deve decidir sobre o que ensinar, como ensinar, por que ensinar, quem deve ensinar, o melhor período para ensinar etc., o que implica uma autonomia sobre o processo educacional ao qual a comunidade é submetida. Intercultural porque a criança indígena, no processo escolar, deve ser levada a transitar nos dois mundos culturais: o indígena e o nãoindígena; ela precisa construir sua identidade indígena e ao mesmo tempo aprender a dialogar com as outras culturas que a cercam, sem se desprender de suas raízes e ancestralidades. Por isso, no currículo escolar das escolas indígenas e, principalmente, na prática de sala de aula, deve estar previsto o trabalho com a diversidade cultural, sendo mostradas as diferenças socioculturais, linguísticas e históricas de cada povo.

Essa prática educativa objetiva, portanto, o respeito pelo outro, no entendimento de que nenhuma cultura ou etnia é superior à outra, apesar de os indígenas terem sofrido, e ainda sofrerem devido ao pensamento que norteou toda a colonização brasileira. Destaca-se que esse conteúdo - pluralidade cultural e interculturalismo - não deveria ficar restrito às discussões das escolas indígenas, mas também estar presente nas discussões das escolas "nacionais", como prevêem os Parâmetros Curriculares Nacionais - PCN (1998), a fim de que percebamos e compreendamos que existe também um pouco do índio e do negro em cada um de nós brasileiros, ou seja, na formação e constituição de nossa identidade.

A educação para o indígena teve como primeiro obstáculo introjetar/impor os costumes eurocêntricos no seio das comunidades nativas, objetivo conseguido principalmente através do ensino da língua portuguesa. No aprendizado de qualquer língua também os valores e concepções são aprendidos:

A linguagem é, quase sempre, o meio mais importante através do qual os povos constroem, modificam e transmitem suas culturas. É por meio do uso da linguagem que a maneira de viver de uma sociedade é expressa e passa, constantemente reavaliada, de uma geração para outra. Os modos específicos de usar a linguagem são, por isso, como documentos de identidade de um povo num determinado momento de sua história (Rcnei, 2005, p.113).

Destaca-se, entretanto, que a valorização da língua portuguesa em detrimento das línguas indígenas não ocorreu só no campo ideológico; a repressão ao uso da língua materna dos indígenas se deu por meio da violência física, muitas vezes chegando à morte, como narra José Oliveira Nunes, professor Xacriabá, de Minas Gerais: “os velhos todos contam que os brancos proibiam o meu povo Xacriabá de falarem o Idioma [...] Se falasse na Língua - ou praticasse a religião - apanhava...ou até morria” (Rcnei, 2005, p. 117).

Diante disso, pensamos que o ensino das línguas indígenas, quando ainda usadas pelas comunidades, deve ser garantido. Nas comunidades multilíngues, o letramento deve ocorrer na língua materna da comunidade indígena, na língua portuguesa e em outras que a 
sociedade indígena necessite e/ou utilize em seu convívio com outras sociedades indígenas, em vez de a língua nativa ser silenciada até desaparecer. Desaparecimento esse que, segundo o RCNEI (2005, p. 118), é muito rápido, pois são necessárias apenas três gerações para uma língua deixar de existir.

Exemplo claro disso foi o que aconteceu no Brasil. Quando os europeus aqui chegaram, falava-se cerca de 1.300 línguas indígenas. Esse desaparecimento efetiva-se da seguinte forma: primeiro, tem-se uma comunidade indígena monolíngue em sua língua materna, depois, diante da necessidade de comunicar-se com o branco, torna-se bilíngue, ou seja, passa a falar a sua língua materna e o português. Por fim, a comunidade volta a ser monolíngue, agora em língua portuguesa, pois esta saiu do seu espaço e finalidade (a comunicação com o branco) e passou a ser utilizada nos espaços antes ocupados pela língua nativa, como na comunicação familiar, nos ritos etc. A língua original da comunidade aborígine, dessa forma, desaparece, já que "deixou de ter funções importantes dentro da aldeia” (Rcnei, 2005, p. 118).

Por fim, a Educação Escolar Diferenciada tem a especificidade em sua base porque deve atender às necessidades peculiares de cada comunidade, visto que existem as sociedades indígenas e não a sociedade indígena. Essa característica é uma resposta ao pensamento de homogeneização cultural e de integração, que durante muito tempo foi a tendência na Educação Escolar Direcionada ao indígena seguida pelo Estado.

Diante do exposto, a questão fundamental é como fazer com que a educação indígena (aquela repassada pela comunidade) faça parte do contexto e objetivos da Educação Escolar Diferenciada. Como fazer com que o letramento escolar seja um instrumento a mais, "uma técnica suplementar, tirada do branco, para resolver os problemas trazidos pelo contato?” (Melià, 1979, p. 60). A resposta a essas questões construirá uma Educação Escolar Indígena em que povos nativos afirmem suas identidades, preservem suas histórias e os levem ao conhecimento de outras sociedades, numa relação intercultural.

\section{CONCLUSÃO}

Entendemos que a necessidade de uma Educação Escolar Indígena surgiu por conta do contato dos nativos com o europeu, povo grafocêntrico que, desde o início do processo de colonização, tratou de implantar seus modelos culturais e ideológicos, silenciando e apagando a forma de ser e viver dos povos brasílicos.

Os padres jesuítas foram os primeiros educadores dos nativos, sendo responsáveis ao mesmo tempo pelo letramento do indígena, pela propagação da fé católica e pela colonização territorial e lingüística do Brasil. A postura educacional adotada desde então somente há duas décadas passou por mudanças: saiu-se do modelo assimilacionista e integracionista para o diferenciado e específico.

Por isso, atualmente a Educação Escolar Indígena está em fazimento tanto nos aspectos relacionados à compreensão das propostas da educação diferenciada quanto na mudança da pedagogia não-indígena de ensino. O letramento está sendo ressignificado para que se permita ao índio conhecer e interagir com as culturas não-índias e, ao mesmo tempo, fortalecer sua identidade étnica.

A construção comunitária da Educação Escolar Indígena configura-se, portanto, como um avanço político educacional no Brasil, haja vista a escola indígena ser um local onde se discutem os problemas que atingem os grupos sociais e mostram-se soluções para 
os mesmos, fazendo com que a educação escolar seja ressignificada e adaptada a outro contexto étnico, contribuindo significativamente para a autonomia dos povos nativos.

\footnotetext{
${ }^{\text {i }}$ Eram aulas autônomas de Latim, Grego e Retórica, sem articulação entre si, ministradas por um único professor.

${ }^{\text {ii }}$ Imposto que incidia sobre a carne verde, o vinho, o vinagre e a aguardente, e visava à manutenção do ensino primário e médio.

iii Esclarecemos que ao utilizarmos a nomenclatura "branco" em contraposição a indígena não fazemos por acreditarmos que cor da pele seja o critério determinante para diferenciar índios de não-índios. Utilizamo-nos dela tão somente por ser consenso se referir dessa maneira ao colonizador ou não-índio.

iv Significa menino em Língua Portuguesa.

v Significa menina em Língua Portuguesa.
} 


\section{REFERÊNCIAS BIBLIOGRÁFICAS}

AZEREDO, F. A Cultura Brasileira: introdução ao estudo da cultura no Brasil. 6 ed. Brasília: Editora UNB, 1996.

BRASIL. Parâmetros Curriculares Nacionais: terceiro e quarto ciclos do ensino fundamental: língua portuguesa. Secretaria de Educação fundamental. Brasília: MEC/SEF, 1998.

CAMARA JR. Mattoso. Introdução às Línguas Indígenas Brasileiras. Rio de Janeiro: ao livro Técnico, 1979.

MARIANI, Bethania. Colonização Lingüística: línguas, política e religião no Brasil (século XVI a XVIII) e nos Estados Unidos da América (século XVIII). Campinas: Pontes, 2004.

MELIÀ, Bartomeu. Educação Indígena e Alfabetização. São Paulo: Loyola, 1979.

MINISTÉRIO DA EDUCAÇÃO, SECRETARIA DE EDUCAÇÃO CONTINUADA, ALFABETIZAÇÃO E DIVERSIDADE. Referencial Curricular Nacional para as Escolas Indígenas. Brasília: MEC/SECAD, 2005.

MUNDURUKU, Daniel. O Banquete dos Deuses. São Paulo: Angra, 2000.

RIBEIRO, Arilda I. M. "Mulheres Educadas na Colônia” In: LOPEZ, E.M.T \&FARIAS FILHO, L.M; VEIGA, G.C. 500 anos de Educação no Brasil. 3ed. 1 reimp., Belo Horizonte: autentica, 2007.

SANTOS, Gersen Luciano dos. O Índio Brasileiro: o que você precisa saber sobre os povos indígenas no Brasil. Brasília: Ministério da Educação, Secretaria de Educação Continuada, Alfabetização e Diversidade LACED/Museu Nacional, 2006. 